\title{
Gender Roles in Traditional Musical Practice: A Survey of the Esan in Edo State, Nigeria
}

\author{
Charles Onomudo Aluede \\ Department of Theatre and Media Arts, Ambrose Alli University, Ekpoma, Edo State, Nigeria
}

KEYWORDS Gender roles; traditional music; ensemble; and subordinate roles

\begin{abstract}
Viewed from the point of uses and functions of African Music, it is readily seen that music in Africa plays an encompassing role. In every event of life - birth to death, music is profusely made in all the ethnic nationalities in Africa. In the various ensembles that make the music used for such events, men form, over half of the instrumentalists, singers and instructors. A striking feature similar to the remark above is that women in Esan play a little above nominal roles in their ensembles. Owing to the situation above, this paper surveys the reasons for the neglect of women. This paper opines that the reasons are largely because of beliefs which are not too empirical and goes ahead to posit that for the continuity in practice of traditional music in Esan, women must be given a due consideration since by gender role definition in the area, they are closer to their children at the formative stages.
\end{abstract}

\section{INTRODUCTION}

Ever since the last decade of the twentie-th Century till the present day, gender issue has been a major and recurring matter in the global discourse. This trend is perhaps rested on the envisioned gains that loom ahead should gender equality be achieved. While frantic attempts are being made each day to bridge the observable gaps, certain factors like religious beliefs, cultural beliefs, anatomical structure, social and economic factors appear to retard the speed and accurate implementation of the equality constantly hoped for in Esan district.

Citing World Bank document, Umoh (2003) says Women in developing Countries do $70 \%$ of all the work in food production, 50\% in Animal husbandry; $100 \%$ in food processing and almost $100 \%$ of domestic and household cares. Talking specifically of the significance of women in Nigeria, Enemuo (1999) says that they have always played five important roles, mother, producer, house manager, community organizer and Socio-cultural and political activists. As opined by Umoh (2003) and Dosuma (2004), Nigerian women constitute about half the nation's population. Despite their number and crucial functions, the division of roles between male and female sexes as prescribed by most cultures. They also assign the subordinate position to women. As a consequence, women have for long suffered various forms of discrimination, inequality and violence. If women are food providers, home mangers, political activists, socio-cultural and Community movers (Adedeji, 1989 and Odonnel, 1998) why the discrimination? Udegbe (1998) intimates us that Christian notion of submissiveness of women relegates them to housewife roles while the men are seen as actors, providers and decision takers. As provided in the Scriptures, so it is in Esan culture. The situation is even that men's roles have been over amplified.

\section{GENDER DEFINED}

Though the term sex and Gender are sometimes used interchangeably (Franklin, 1988), there is a strict distinction between them. Sex simply refers to the biological or the physiological characteristics -hormonal and Anatomical unique to being either male or female. In the view of Roldan and Beneria in Zapata (1997), the term gender refers to the beliefs, personality traits, attitudes, sentiments and values, conducts and activities that distinguish men from women through a process of social formation that demonstrates specific characteristics. In the same view, Bird and Melville (1994: 34) see gender as "psychological, sociological and cultural aspects of being male and female". One more definition worthy of mention is that of Marcela (1995) who also defines gender as a social category that refers to and facilitates the analysis of the different roles, responsibilities, rights and opportunities and limitations of men and women within the family, the community, the society, the culture etc. In Africa and indeed in the whole world, gender roles are ordained and learned and these roles consist of masculine and feminine behaviours that members of the society are encourage to act out, such as husband or wife, father or mother, boy or girl. Such roles structure our choices and guide 
our behaviours in acceptable manners within the community we operate. Talking about socially defined set of expectations or norms - gender roles.

Franklin (1988) says traditionally, mothers have changed diapers, bathed and fed babies and acted as children's primary care givers and nurturers although fathers occasionally held babies but are more comfortable engaging in robust and playful activities with their children.

The Esan: Its location and ensemble membership in the locale

Esan, a language spoken and also a name given to a group of people who occupies the North Eastern part of Edo State, Nigeria is also called Ishan due to Anglicism-a result of colonial rule. This people are believed to be of Benin origin, thus often referred to as of Edoid extraction (Okojie, 1960; Egharevba, 1968; Okpoko, 1993; Okoduwa, 1997). This province has a landmass of about 1,162 square miles and a population of 398,103 dwellers; owing to its historical origin, the socio-political structure of the people relies greatly on that of Bini and so patrilineal inheritance is practiced in the area. Before now, Esan people has had very many musical ensembles, over half of them are now extinct as a result of Christianity and urbanization. Right now, one can safely talk of the ensembles below:

$\begin{array}{ll}\text { 1. } & \text { Ohoko } \\ \text { 2. } & \text { Igbabonelimin } \\ \text { 3. Asonogun } \\ \text { 4. } & \text { Ijieleghe } \\ \text { 5. } & \text { Ikoghe } \\ \text { 6. } & \text { Ukpukpe }\end{array}$

Ohoko is the musical ensemble of the hunters' guild and is basically for men and spectators are unrestricted.

Igbabonelimin is a musical ensemble for men and spectators are unrestricted.

Asonogun is for both sexes but men play the instruments. Ijeleghe is an acrobatic dance of girls and men are the instrumentalists and leaders. For Ikoghe music, which is basically performed for women infidels by women, unconventional musical instruments like bottles, pans, plates and torn drums are used (Aluede and Ekewenu, 2003). Ukpukpe is a basically music, dance and drama performed by women dressed in men's clothes for a dead elderly woman, the instruments used are just a bell and hand clapping.

Factors Responsible for the Subordinate Roles of Women in Esan Ensemble
There are so many factors responsible for the present status of women in Esan musical ensembles. So that more questions may not be raised than possible answers in this treatise, the six factors below will be given some consideration.

(a) Religious factor

(b) Marriage patterns

(c) Socio - political factor

(d) Anatomical structure

(e) Economical factor

(f) Anthropomorphic attributes of Esan drums.

(a) Religious Factor: Every one seems agreed, Muslims, Christians and traditional people that women are not expected to be at the forefront in religious matters. In all the religions, females are at a biological disadvantage.

(Schapera, 1971; Friedson, 1996) and Strobel (1996: 114) specifically says of Africans that "Menstrual blood is thought to be polluting; a menstruating female therefore does not perform such religious duties as praying, fasting during the month of Ramadan. A man may avoid some pollution by avoiding a menstruating woman, but a woman cannot escape pollution; it is part of her nature". In the Old Testament, the Bible forbids a menstruating woman from temple work but allows the husband free movement in and out the temple.

In Esan, by the nature of wood used in drum construction and its associated consecration, the drum assumes a supernatural status. That a drum assumes a supernatural status is not novel (Wacksmann, 1965). This development makes it practically impossible if not anathema for a woman to hold or even play such a drum because it is believed that such an act could cause hemorrhage and instant death.

(b) Marriage Factor: Levirate system of marriage is still fashionable in this locale. By this system of marriage, a son inherits a late father's or elder brother's wife. These wives are invariably older than the new husbands in most cases and the women are expected to faithfully wife their new husbands without hesitation. In this community, girls are taught wifely duties during puberty rites and during festivals. The ideology of female subordination are also taught in music and dance and so women are not for any reason to compete with the men folk in the enjoyment of certain musical genres or playing certain musical instruments. In line with this opinion, Bebey (1975), says because the drum is in certain circumstances, is equated with a man, a rather exceptional 
man at that, whose powerful voice is capable of sending messages far and wide, women must consequently treat it with the same respect that they should toward their men folk. Women are therefore not permitted to touch the drum under any circumstance. This idea inhibits the women in Esan from aiming at the use of drums in some of their ensembles.

(c) Socio Political Factor: In the present democratic era, very few Nigerians are politically empowered but in all, women are the most disempowered. If women population in Nigeria is about $50 \%$ of the overall Nigerian population, one will agree that the present appointment into government offices is yet to reflect that.

Dasuma (2004) says political empowerment of women enables them to become part of the decision-making organs or agencies so that issues related to women will not be over looked. In Esan, even when few affluent women are honoured with chieftaincy titles, they are not part of decisionmaking at the grass root level and so what seems unpleasant to them remains underdressed.

(d) Anatomical Factor: Anatomically, the present status of women has to do with God's ascription of roles. During pregnancies in women, their contributions are usually unstable if not retarded. This in turn affects the organizational structure of any establishment and the Esan women are not left out. Just as ritual and agricultural calendar are obeyed in Esan by men before performances are held, it is viewed that prenatal, natal and post natal commitments of women make them too homely for out door performances.

Housewifery is dying away with great rapidity because of women's involvement in economic activities to support the running of the family. In the face of hardship associated with certain government polities in the past decades till date.

(f) Anthropomorphic Attributes of Esan Drums: Anthropomorphism means the ascription of human characteristics to what is not human (chambers dictionary 2001). Although not within the purview of the paper, anthropomorphic attributes of drums stem from the fact that drums in Tibet, drum sticks of Ashanti sacrificial drums are made of human skin and ornamented with human skulls (Kamien, 1988). Hart specifically says, "The most distinctive Damarus are made of human skull"( Hart, 1990:15). Although Esan drums are necessarily not made of human skull or skin, they are made of spirited trees like Akwobisi or Akpobrisi in urhobo (Ubrurhe, 2003), Ohankin, hides of animals of strong powers and are further consecrated. This consecration makes them a boiling point of numerous energies and so; they are now seen as gods and super humans. They are used for healing purposes, cursing evil hands in the society, communication with spirits and other deities. Due to the fact that the powers of Esan drums are in exhaustible, their use in the regulation of the community mores namely healing, cursing, communication, etc. are esoterically kept and so women are not only seen as impure but also denied of membership into the circles where such body of knowledge is taught. Of the many age grade initiation rites available to men in Esan, women simply observe the puberty rite in and this phenomenon is becoming extinct in some Esan towns.

\section{OF AN ETHNO - MUSICOLOGICAL RESPONSE}

Much disservice would have been done and harm caused if a paper like this fails to give remedies to the myraid of problems identified. Without out doubt, religious factor appears to be the whole crux of gender inequality in Esan. In this region today, it is not out of place to find women pastors, reverend sisters, traditional healers, witch doctors and spiritists. No one is contented any longer with the opinion that they are impure before men or god/God. These women work at the looms, farm, trade, in the various offices to increase family wealth. Right now, nothing is viewed wrong about this development and besides; unfounded views of centuries ago can no longer hold sway in this new era

Since women are caregivers to children and husbands, since they are closer to the children and their first teachers ever, some musical ideals worthy of continuation should be made known to them for onward transmission to their children. If men can keep rules relating to the time and season of the use of the drums in the community, women too are more likely to ensure its continuity too because the concept of marriage in Esan revolves around keeping certain basic information in matrimony hermetic.

On the issue of levirate marriage in Esan and as may be found else where religion also forms the strong basis and reason for such a development. However, culture is dynamic. Practices that are repugnant to natural justice should be abbreviated. Wives should not been seen as properties to be shared or made to serve toddlers 
that once served them. In Esan today there are instances of one's elder brother also being a step father or cousin and this develop-ment puts the woman in messy situation. When a practice like this done away with, women will have a status that will make them be at par with their men counterparts. If women have distinguished themselves in other areas, what is in the cultural aspect they can not propagate? Observing the very highly esteemed spiritual status of women in our societies Nabofa (1990) and Aluede (2003) have talked of women dancing nude at mid nights to curse through music and dance human forces responsible for unexplained drought in the rainy season in Urhobo and Esan lands respectively. If the women's music, dance and curses are so highly recognized to be efficacious why are they schemed out in ethno musicological realms?.

Arising from the non-involvement of women in the key ensembles in Esan is the dearth of the practitioners. In the past every village had village ensembles, men of today are busy with economic activities and some have even lost contact with their hometown as a result of urban drift. If both men and women are involved in the musical practice in such areas, this move will absolve the vacuum created by those in search of greener pastures in the cities, thus culture will be kept alive.

Sexual differences are facts of biology, but the particular significance societies attach to sexual differences is a human-cultural creation. Gender is a social construct while sex is a biological condition (Strobel, 1996). Not wanting to give women a place is partly responsible for the over amplification of gender roles in Africa and indeed in Esan Nigeria. Do women menstruate perpetually? Do they menstruate every day of the month? Can't they function when not menstruating? Can't they function after menopause? The questions above do not necessarily need answers but point to the flaws in the ideas held sacrosanct by the Esan people.

\section{CONCLUDING REMARKS}

In an attempt to discuss the subject matter of this paper, gender as a term was defined, ensembles and ensemble composition in Esan was reviewed. In the same strain, factors responsible for the subordinate roles ascribed to the women in Esan were highlighted and discussed in some details. In all, the paper holds that if honorific titles can be given to the women because of their contributions to Esan development, if they have functioned as orthodox and native doctors, seers and mediums, they should be more involved in Esan musical practice to ensure musical continuity because female impurity at one stage or the other is not empirical but unrealistic.

\section{REFERENCES}

Adedeji, A. 1989. African Women Development: Selected Statements. Addis Ababa: UNCECA.

Aluede, C.O and D. B. Ekewenu. 2003. "Social control and the performance oftraditional African music: A study of Ikoghe music of the Esan,Nigeria." Castalia, 13(i): $1-10$

Bebey, F. 1975. African Music: A People's Art. London: George Harrap and Co.

Dasuma, A.M. and L. O. Odoma. 2004. "Empowering Nigerian women politically for Economic rehabilitation and reliance; possible hindrances andsolution." A conference paper presented in NARD Okene $13^{\text {th }}$ $17^{\text {th }}$ Sept., 2004.

Enemuo, F.C. 1999. "Gender and women Empowerment," in R. Anrifowose and F.C. Enemuo (eds.), Elements of Politics. Lagos: Malthouse Press.

Egharevba, J.U. 1968. A Short History of Benin. Ibadan: Ibadan University Press.

Franklin, C.W. 1988. Men and Society. Chicago: Nelson Hall Press.

Friedson, S.M. 1996. Dancing Prophets. Chicago: Chicago University Press.

Hart, M. 1990.. Drumming at the Edge of Magic. New York: Harper Collins Publishers

Kamien, R. 1988. Music; An Appreciation. New York: Mc Graw-Hill Publishing Company

Mercela, B. 1995.From a speech on perspectives de Generio en la Alfabetizationy Education held in Medellin.

Odonnel, I.T. 1993. Women and Conflict: Focus on Gender or Farm 1(2) pp. 1-10..

Okoduwa, A.I. 1997. Studies in Esan History and Culture. Benin City: Omon Uwessan Press.

Okojie, C.G. 1960. Esan Native Laws and Custom. Lagos: John Okwesa Press Ltd.

Okpoko, A.C. and K.A. Agbontaen 1993. "Edo traditions of Origin”, in B. W. Adah (ed.), Some Nigerian People. Ibadan: Res Charles Publications.

Schapera, I. 1971. Married life in an African Tribe. London: Pelican Books

Strobel, M. 1996. "Women in religious and secular Ideology", in M. Jean Hay and S. Sticher (eds.), African Women South of the Sahara. London: Longman Group Limited.

Ubrurhe, J.O. 2003. "Communication with Herbs an aspect of Urhobo Medicine." Castalia, 13(i): 32 42 .

Umoh, E.D. 2003. "Female Gender and development in Nigeria: A Case Study of Akwa Ibom State." Castalia, 13(i): 11-19.

Wacksmann, K. 1965. "Primitive Music." Encyclopaedia Britannica, 15: 1072- 1078

Zapata, L.O.L. 1997. Literacy: Caught in a new Trap. Journal of Adult Educationand Development IZZ DW No 48: 61-96. 